\title{
COMMENTS
}

\section{False Statements to Federal Agents: Induced Lies and the Exculpatory No}

\author{
Giles A. Birch $\dagger$
}

\section{INTRODUCTION}

The federal false statements statute, 18 USC $\S 1001$, makes it a felony to lie to a federal agency. ${ }^{1}$ Since the enactment of its predecessor in $1934,{ }^{2} \S 1001$ has been used to prosecute a wide variety of defendants. The most controversial use of the statute is its application to suspects who lie to federal agents during criminal investigations. $^{3}$ Disturbed by the potential for abuse that this presents to federal police, some courts have created an "exculpatory no" exception to $\S 1001$ for defendants who deny their guilt under questioning.

Other courts have expressed reservations about this judicially created exception, but no circuit has rejected the exculpatory no directly. Even the courts that have adopted the doctrine explicitly,

$\dagger$ A.B. 1985, Harvard University; J.D. Candidate 1991, The University of Chicago.

18 USC $\$ 1001$ (1988). The statute provides in full:

Whoever, in any matter within the jurisdiction of any department or agency of the United States knowingly and willfully falsifies, conceals or covers up by any trick, scheme, or device a material fact, or makes any false, fictitious or fraudulent statements or representations, or makes or uses any false writing or document knowing the same to contain any false, fictitious or fraudulent statement or entry, shall be fined not more than $\$ 10,000$ or imprisoned not more than five years, or both.

218 USC $\$ 80$ (1940).

3 The problem has generated a large amount of commentary. See, for example, Note, Constitutionally Privileged False Statements, 22 Stan L Rev 783 (1970); Note, Fairness in Criminal Investigations Under the Federal False Statement Statute, 77 Colum L Rev 316 (1977); Note, Criminal Liability for False Statements to Federal Law Enforcement Officials, $63 \mathrm{Va}$ L Rev 451 (1977); Note, Prosecutions for False Statements to the Federal Bureau of Investigation-the Uncertain Law, 29 Syracuse L Rev 763 (1978); Note, Judicial Reluctance to Enforce the Federal False Statement Statute in Investigatory Situations, 51 Fordham L Rev 515 (1982). 
however, have had difficulty defining it. The existing definitions of the exculpatory no depend on arbitrary distinctions. Some courts attempt to distinguish between simple denials and more complex, or "affirmative," falsehoods. Other courts attempt to distinguish between investigative and administrative inquiries. And even courts that use the same definition of the exculpatory no have reached contradictory conclusions in cases with similar facts.

The law in this area needs more than clarification. The legislative and constitutional arguments in favor of the exculpatory no doctrine are tenuous. Moreover, they appear to miss the real issue. Guilty suspects asked incriminating questions are very likely to lie, and investigators seem to prefer those lies to silence. Prosecuting a suspect for telling lies that an agency wants to hear perverts the statute's purpose of protecting agency information-gathering. The exculpatory no fails to adequately separate these perverse prosecutions from those that properly fall within the statute's coverage.

This Comment proposes an affirmative defense, the "induced lie," to replace the exculpatory no doctrine. Section I reviews the origins of $\S 1001$, and identifies the problems caused by its use in the investigative context. Section II examines the judicial creation of the exculpatory no and criticizes the current formulations of the doctrine. Section III defines the proposed induced lie defense. The induced lie makes the statute inapplicable when federal agents fail to warn the people they interview that lying is a crime and that silence is permissible, unless a response is required or the interviewee is predisposed to lie. Because it is defined by the abuse of the statute's purpose, this defense rests on more solid legal footing and provides a better remedy for abuse than does the exculpatory no exception.

\section{The Origins and Investigative Use of Section 1001}

While Congress drafted $\S 1001$ with a particular problem in mind, its broad language reaches far beyond that original concern. This Section traces the origins of $\S 1001$ and examines its relatively recent use against persons suspected of other crimes. It then identifies the problems of using the statute against people who fear self-incrimination by analyzing the incentives of interrogators and their subjects.

In 1934, the Secretary of the Interior requested that Congress amend the false claims statute ${ }^{4}$ to deter false statements on regula-

18 USC $\S 80$. 
tory reports..$^{5}$ In response, Congress enacted the statute now codified as $\S 1001 .^{6} \mathrm{By}$ punishing false statements, $\S 1001$ protects federal agencies from the effects of false information. ${ }^{7}$

Although the statute was designed to solve the problem of false statements by people required to report to a federal agency, $\S$ 1001's broad language makes no distinction between required and voluntary responses. Accordingly, the Supreme Court has read $\S$ 1001 expansively. The Court has held that the statute applies to verbal as well as written reports, ${ }^{8}$ to non-regulatory ${ }^{9}$ and investigative $^{10}$ agencies, and to situations where there is no legal obligation to speak. ${ }^{11}$

In the 1950s prosecutors began to apply the extraordinary breadth of $\S 1001$ against suspects who lied to investigators. ${ }^{12}$ This new application gives an enormous and unprecedented power to the federal police, and, in doing so, raises two problems. The first is that punishing people for lying in response to incriminating questions gives powerful impetus to "inquisition as a method of criminal investigation."13 Although lying to the police is obviously objectionable, police authority does not traditionally include the power to punish suspects who lie. ${ }^{14}$ By giving a federal investigator

\footnotetext{
- Specifically, the Secretary was concerned, "with respect to the transportation of "hot oil," " about "the lack of a law under which prosecutions might be had "for the presentation of false papers.' " United States v Gilliland, 312 US 86, 94 (1941). The false claims statute, however, applied only to false statements "relating to the fraudulent causing of pecuniary or property loss." Id at 92 (quoting United States v Cohn, 270 US 339, 346-47 (1926)).

- Id at 94-95. Enacted in 1948, the present form of the statute divides the false claims statute into two sections: the false claims provisions, 18 USC $\$ 287$, and the false statements provisions, 18 USC $\S 1001$. "There is no indication that the revision [in the language] was intended to work any substantive change." United States v Bramblett, 348 US 503, 508 (1955).

" See Gilliland, 312 US at 93 (holding that Congress intended to "protect the authorized functions of governmental departments and agencies from the perversion which might result from the deceptive practices described").

- United States v Beacon Brass Co., Inc., 344 US 43, 46 (1952).

- Bramblett, 348 US at 509 (reinstating a conviction of a former member of Congress for falsely representing to the House Disbursing Office that a friend was entitled to compensation as his official clerk).

10 United States v Rodgers, 466 US 475, 477 (1984) ("The statutory language clearly encompasses criminal investigations conducted by the FBI and the Secret Service, and nothing in the legislative history indicates that Congress intended a more restricted reach for the statute.").

${ }^{11}$ The Court has taken the view that any "statutory basis for an agency's request for information provides jurisdiction enough to punish fraudulent statements under $\$ 1001 . "$ Bryson v United States, 396 US 64, 71 (1969).

12 The earliest example is United States $v$ Levin, 133 F Supp 88, 89 (D Colo 1953).

23 United States v Bush, 503 F2d 813, 815 (5th Cir 1974).

14 When thinking about criminal investigations, we expect a traditional dance: Columbo asks the suspect questions; the suspect tells inventive and plausible lies; Columbo doggedly
} 
the authority to demand that she not be lied to, under the threat of harsh punishment, the statute turns an investigation into a series of confrontations in which the guilty suspect must have the fortitude to remain silent upon accusation, since he faces prosecution for any response: the truth admits the crime being investigated; a lie violates $\S 1001$. Given the penalties for either response, a guilty suspect might seem likely to opt for silence. But silence in the face of accusation is an extremely unnatural response,${ }^{15}$ and, as a practical matter, a suspect will usually expect the investigator to view his silence as an indicator of guilt and to intensify her efforts. ${ }^{16}$

A guilty suspect who is asked an incriminating question by a federal agent thus faces a harsh trilemma: he must confess his crime, lie and risk punishment under $\S 1001$, or remain silent when silence may be treated as an admission of culpability. A statute that creates such a trilemma punishes suspects for refusing to admit their guilt. ${ }^{17}$

The investigative use of $\S 1001$ presents more than a policy problem, however. Although the purpose of the statute is to protect agency information-gathering, a criminal suspect may be prosecuted under $\S 1001$ for lying even when the agents concerned would have preferred a lie to silence. The root of this problem is

uncovers the truth and confronts the perpetrator with the growing evidence of his guilt; the lies become less persuasive; Columbo proves his case; and the suspect confesses. The suspect's role is to evade detection as much as Columbo's role is to unravel the web of his deceit.

1s United States $v$ Goldfine, 538 F2d 815, 822 n 2 (9th Cir 1976).

16 A standard pre-Miranda work on interrogation recommended that police remind suspects that their interrogators would infer guilt from silence to discourage suspects from exercising their right to silence. Fred E. Inbau and John E. Reid, Criminal Interrogation and Confessions 111 (Williams \& Wilkins, 1962), quoted in Miranda v Arizona, 384 US 436, 454 (1965).

17 Recognizing this problem, the Model Penal Code omits sanctions for lies told to investigators. American Law Institute, Model Penal Code, Official Draft and Explanatory Notes, Comment to $\S 241.3$ at 150-52 (1985). The National Commission on Reform of Federal Criminal Laws, popularly known as the Brown Commission, made a similar recommendation. The Commission was set up in 1966 "to make a full and complete review and study of the statutory and case law of the United States for the purpose of formulating and recommending to the Congress legislation which would improve the Federal System of Criminal Justice." An Act to Establish a National Commission on Reform of Federal Criminal Laws, Pub L No 89-801, 80 Stat 1516 (1966). The Commission issued its Final Report in 1971, which included $\S 1352$ (false statements) and $\S 1354$ (false accusations and false reports of crime). Section 1352 did not penalize statements given in the course of a criminal investigation unless "given in an official proceeding or the declarant is otherwise under a legal duty to give the information." $\S 1352(3)$. The final push to pass a revised federal criminal code was defeated by a conservative filibuster over controversial issues including the death penalty, obscenity crimes, and sex offenses. See 1982 Cong Q Alman 416. 
ignorance. Not only do guilty suspects face a trilemma, but most of them fail to realize it, making it nearly certain that they will lie. The near-certainty that suspects will lie allows investigators to set up violations that they fully expect to occur.

There are two potential areas of ignorance. First, although the Miranda warning reminds arrestees that they may not legally be compelled to speak, ${ }^{18}$ suspects questioned before arrest need not be warned. ${ }^{19}$ Without a warning, some suspects may not even know that they may remain silent. Believing that they must speak, these suspects face the dilemma of admitting their guilt or lying. ${ }^{20}$

Second, and more important, even suspects aware of their right to remain silent are unlikely to know of the punishment in store for them if they lie, ${ }^{21}$ and federal investigative agencies do not appear to have policies of warning suspects that they may be punished under $\S 1001 .^{22}$ If a guilty suspect is aware of his right to remain silent but is not aware of the penalty for falsehoods, he is very likely to lie. And because a simple exculpatory no will often be no more convincing to an investigator than silence, the suspect is likely to offer more than a flat denial.

18 Miranda, 384 US at 467-68.

19 Beckwith v United States, 425 US 341, 347 (1976).

${ }^{20}$ See, for example, United States v Dempsey, 740 F Supp 1299, 1306 (N D Ill 1990):

[T] ]he government admitted at the hearings that it visited these defendants with the purpose of obtaining incriminating statements, and it clearly asked questions which were designed to elicit admissions. The government received admissions from some of the defendants. When it received denials from certain defendants rather than admissions, the government later brought charges against these defendants under 18 USC $\S 1001$. Clearly these defendants suffered an increased threat of criminal liability whether they admitted or denied wrongdoing. The only way these defendants could have avoided this Catch-22 situation would have been by refusing to respond to the accusations altogether, but none were advised of their Miranda rights.

${ }^{21}$ In the context of an investigation, $\$ 1001$ punishes behavior not usually considered criminal. Columbo's suspect probably would be surprised to find himself indicted not just for the crime Columbo was investigating but for several counts of lying to Columbo as well. He might be even more surprised to discover that the potential penalty for each lie exceeds that for many more serious felonies, including perjury. See note 29.

${ }^{22}$ It is the policy of the IRS, for example, to warn subjects of interrogation that they may remain silent, but the policy makes no mention of $\S 1001$. See Internal Revenue Manual § 9384.2 at 9-226.4 (1989). The FBI has no policy of warning interviewees that lying is a crime, nor do the Bureau of Alcohol, Tobacco and Firearms or the Customs Service. Conversations with author: Michael Pavia, Principal Legal Adviser, FBI, Chicago (October, 1990); Special Agent Jerry Singer, BATF, Chicago (October, 1990); Special Agent Gary Hartwig, Customs Service, Chicago (October, 1990). The only cases the author has found that mention that the defendant was warned about $\S 1001$ are Customs cases. United States $v$ Grotke, 702 F2d 49, 53 n 4 (2d Cir 1983) (noting that a Customs form warned the defendant that lying to a Customs agent was a crime); United States v Fitzgibbon, 619 F2d 874, 880 (10th Cir 1980) (same). 
Agents may deliberately take advantage of a suspect's ignorance of his predicament. For example, if an investigator finds it difficult to prove some elements of a crime, ${ }^{23}$ she can ask questions about other elements to which she already knows the answers. If the suspect lies, she can then use the crime she has prompted as leverage or can seek prosecution for the lie as a substitute for the crime she cannot prove. A prosecution under these circumstances is a perversion of the statute's purpose. The agent is not using $\S$ 1001 to protect her information-gathering process but is instead using § 1001 to manufacture convictions.

Even if agents do not consciously plan to lure suspects into violations, prosecutors may misapply the statute by prosecuting cases in which the agent would have preferred a lie if she had thought about it. In fact, the common practices of federal agencies seem to suggest that this preference is the norm. Investigative agencies could easily increase compliance with $\S 1001$ by simply warning suspects, or any interviewees, that they risk prosecution if they lie. It seems likely that investigative agencies do not make it their policy to warn suspects of potential penalties under $\S 1001$ because they prefer that suspects talk rather than remain silent. Cross-examination may reveal truths that a suspect would rather conceal, and alibis may provide leads for further investigation. Silence, on the other hand, does not help an investigator find the evidence needed to prove her case, even if it may indicate guilt. ${ }^{24}$

If investigative agencies have chosen to avoid chilling the flow of information by not warning suspects about $\S 1001$, then it seems perverse to prosecute a suspect for violating a statute designed to protect agency functions when the agency itself has decided that increased compliance with the statute would hinder, not aid, its functions. In these circumstances, prosecutions for deliberately undeterred lies seem more expedient or vindictive than just. ${ }^{25}$

${ }^{23}$ For example, intent is often particularly hard to prove in official corruption cases. Was the payment a bribe, a loan or a gift? Several exculpatory no cases involve defendants suspected of paying or receiving bribes but charged only with violations of $\S 1001$. See, for example, United States v Stark, 131 F Supp 190 (D Md 1955); Paternostro v United States, 311 F2d 298 (5th Cir 1962); and United States v Bush, 503 F2d 813 (5th Cir 1974).

${ }^{24}$ At trial, while a lie may be used as substantive evidence of consciousness of guilt, silence may be used at most to impeach the defendant: evidence of silence prior to a $\mathrm{Mi}$ randa warning may be used to impeach (Jenkins $v$ Anderson, 447 US 231, 240 (1980)), but evidence of silence following a Miranda warning may not be used (Doyle v Ohio, 426 US $610,618(1976))$.

${ }^{25}$ The Supreme Court held in United States v Yermian, 468 US 63, $68-70$ (1984), that knowledge that a statement is "in any matter within the jurisdiction of any department or agency of the United States" is not required for a conviction under $\$ 1001$. Although the 


\section{The Exculpatory No Doctrine}

Many of the district court judges who first addressed the use of $\S 1001$ in investigations were disturbed by the statute's sweeping grant of authority to federal law enforcement officers. ${ }^{28}$ Appellate courts, too, have been troubled by the prosecution of suspects who have often done little more than plead "not guilty" outside the courtroom. ${ }^{27}$ The courts devised the exculpatory no doctrine to limit the harsh effects of a broadly worded statute. This Section presents the justifications the courts have offered for creating an exception, a brief presentation of two widely used forms of the exculpatory no, and a criticism of the current doctrine.

\section{A. Justifications}

Broadly speaking, the courts have asserted two justifications for the exculpatory no doctrine. The first is an argument from legislative intent: when Congress gave the Secretary of the Interior the powers he sought, it could not have intended that this new authority be used against criminal suspects who have done no more than deny their guilt. ${ }^{28}$ Courts have used three arguments to support this contention. First, they have observed that the penalty for lying to investigators under $\S 1001$ is greater than the penalty for perjury, despite the absence of procedural protections under $\S$ $1001 .^{29}$ Second, they note that in a criminal investigation a lie by a

Court did not decide whether there was any mens rea requirement with regard to the jurisdictional issue, the Ninth Circuit, among others, has since held that the federal element of a prosecution under $\S 1001$ is a strict liability element. United States $v$ Green, 745 F2d 1205, 1209 (9th $\mathrm{Cir}$ 1984). Therefore, it would seem that a defendant could be successfully prosecuted for lying to an undercover agent. This aspect of the substantive law, like the failure of agencies to warn interviewees of their potential liability, makes some of the current applications of the false statement statute seem draconian.

${ }^{28}$ See Levin, 133 F Supp 88; Stark, 131 F Supp 190; United States v Davey, 155 F Supp 175 (S D NY 1957); United States v Philippe, 173 F Supp 582 (S D NY 1959).

${ }^{27}$ See Goldfine, 538 F2d at 821-22 (Ferguson dissenting).

23 See, for example, Paternostro, 311 F2d at 305; Stark, 131 F Supp at 205.

29 See United States $v$ Chevoor, 526 F2d 178, 183 (1st Cir 1975) (noting the severity of the sanctions under $\S 1001$ and the lack of safeguards that are normally provided in perjury prosecutions, "primarily the formality of the oath"); United States v Ehrlichman, 379 F Supp 291, 292 (D DC 1974) ("There is no requirement of an oath, no strict rule of materiality, and no guarantee that the proceeding will be transcribed or reduced to memorandum."); Friedman, 374 F2d at 367; and Levin, 133 F Supp at 90. In United States v Poutre, the court reversed a conviction under $\S 1001$ because the agent's testimony at trial was contradicted by his notes and the partial transcript of the interview. 646 F2d 685, 686-87 (1st Cir 1980).

The maximum penalty for a violation of $\S 1001$ is $\$ 10,000$ or five years in prison. Lying to a process server, as in United States v Bedore, 455 F2d 1109 (9th Cir 1972), is worse than tssaulting one, which carries a meximum penalty of $\$ 300$ or one year. 18 USC $\$ 1501$ (1988). 
suspect does not harm the agency: "a competent government investigator will anticipate that the defendant will make exculpatory statements," and thus a "defendant who meets [the competent investigator's] expectation cannot possibly pervert the investigator's police function."30 Finally, some courts have straightforwardly objected to the breadth of the language. Congress could not have meant that "virtually any false statement, sworn or unsworn, written or oral, made to a Government employee [should] be penalized as a felony." ${ }^{11}$ Such a broad reading of the statute creates a trap for the unwary. ${ }^{32}$

The second justification for the doctrine is constitutional. As the Fifth Circuit commented in an oft-quoted footnote, "Undoubtedly the judicial gloss put on $\S 1001$ by the 'exculpatory no' decisions originates at least in part from latent distaste for an application of the statute that is uncomfortably close to the Fifth Amendment." $"$ The courts have not been particularly clear about the nature of their constitutionally prompted discomfort. The principal concern is the policy problem identified above: the government should not "be allowed to coerce a person into admitting wrongdoing, on pain of prosecution." 34

The maximum penalty for perjury is $\$ 2,000$ or five years. 18 USC $\S 1621$ (1988). The United States Sentencing Guidelines ("USSG") eliminate the disparity in the penalty by making false statements a level 6 offense while perjury has a base level of 12. Compare USSG § 2F1.1 (fraud and deceit) with $\S 2 J 1.3$ (perjury or subornation of perjury).

Prosecutions for perjury under 18 USC $\S 1621$ were subject to the "two-witness" rule, which required that proof of the falsehood be made by two independent witnesses or by one witness plus independent corroborating evidence. Weiler v United States, 323 US 606, 60910 (1945). The rule did not apply to prosecutions under $\S 1001$. It is not surprising to find, therefore, that some of the early cases involved defendants who had lied under oath. See, for example, Paternostro, 311 F2d at 300; and Stark, 131 F Supp at 191.

so United States v Medina de Perez, 799 F2d 540, 546 (9th Cir 1986). See also Philippe, 173 F Supp at 584.

s1 Bedore, 455 F2d at 1110.

32 "An inquiry might be made of any citizen concerning criminal cases of a minor nature, or even of civil matters of little consequence, and if he wilfully falsified his statements, it would be a violation of this statute." Levin, 133 F Supp at 90.

ss United States $v$ Lambert, 501 F2d 943, 946 n 4 (5th Cir 1974) (en banc) (deciding that the FBI did have 'jurisdiction' for the purposes of $\S 1001$, in a case involving the false report of a crime). Judge Chesnut, in the district of Maryland, used sweeping rhetoric to invoke the Fifth Amendment. He argued that while the Fifth Amendment right to remain silent in the face of accusation is "not strictly applicable here[, investigative use of $\S 1001$ ] seems inconsistent with this great bulwark of individual liberty." Stark, 131 F Supp at 207.

${ }^{34}$ United States $v$ Payne, 750 F2d 844, 862 (11th Cir 1985) (extending the exculpatory no exception to prosecutions under 18 USC $\$ 1006$, which punishes false statements in connection with the Federal Land Bank program); see also Davey, 155 F Supp at 178. 
B. Current Formulations

Despite frequent cross-citation and broad agreement on the justifications for the exculpatory no, different circuits have crafted different forms of the doctrine. At present, there are two broad categories of response to investigative use of $\S 1001$ : the Fifth and Eleventh Circuits have created exceptions that apply when either the legislative intent or the Fifth Amendment arguments are implicated, and a group of courts led by the Ninth Circuit has created an exception that applies only when both concerns are present. Other circuits have also grappled with the exculpatory no doctrine and offered their own variations.

1. Exceptions requiring only one justification (Fifth and Eleventh Circuits).

The Fifth Circuit first described the exculpatory no in Paternostro $v$ United States as applying to defendants who have not made a claim against the government, have not sought "to obtain or retain any official position or employment," and have not "aggressively and deliberately initiate[d] any positive or affirmative statement."3s The court held that Congress did not intend for these responses to be considered "statements" under $\S 1001 .^{36}$

The central issue in this version of the exculpatory no is the characterization of the defendant's statement. The Fifth Circuit has attempted to maintain a "valid distinction between negative exculpatory denial of a suspected misdeed and an affirmative representation of facts."37 One court explained that a mere "no," without elaboration, is not enough to demonstrate an intent to pervert the function of the agency involved..$^{38}$

Some Fifth Circuit cases also look to the Fifth Amendment for an independent justification for the exception. Under this formulation, a conviction under $\S 1001$ can be reversed if a truthful answer to the question would have been incriminating, regardless of the nature of the actual response. ${ }^{3 \theta}$ Recent decisions in the Fifth Circuit, however, have used this justification inconsistently. In United

ss 311 F2d at 305.

36 Id at 302-05.

37 Bush, 503 F2d at 818. See also United States $v$ Johnson, 530 F2d 52, 55 (5th Cir 1976) (affirming conviction of defendant who procured false affidavit from friend in attempt to account for unreported income).

ss United States v Schnaiderman, 568 F2d 1208, 1213 (5th Cir 1978).

3s Bush, 503 F2d at 818-19; Schnaiderman, 568 F2d at 1213. In neither case, however, did the court rely exclusively on this argument to reverse the defendants' convictions. 
States $v$ Anderez, the court decided that because the defendant could not have feared self-incrimination, his decision to lie was not protected by the doctrine..$^{40}$ In United States $v$ Hajecate, however, the defendants were given the benefit of the exculpatory no doctrine merely because the court believed that the question asked was investigative rather than administrative. ${ }^{41}$ The court never considered that it would not have been incriminating for the defendants to give a truthful answer at the time. ${ }^{42}$

Unlike the Fifth, the Eleventh Circuit has maintained a strict separation of the two justifications. In United States $v$ Payne, the court distinguished the legislative intent analysis from the self-incrimination concern and applied the latter to a prosecution under 18 USC $\S 1006$, which prohibits false statements in matters involving Federal Land Banks. ${ }^{43}$ The court characterized this version of the exculpatory no as an affirmative defense $\mathrm{e}^{44}$ and put the burden of production on the defendant to show that "truthful affirmative answers would have been incriminating, or ... that he or she reasonably believed that truthful affirmative answers would have been incriminating." 45 In United States $v$ Tabor, however, the court emphasized that the legislative intent basis for the exculpatory no doctrine had continued vitality. ${ }^{46}$ Whether or not the defendant actually feared self-incrimination, the question was designed to elicit an incriminating response, and " $[t]$ he answer was essentially an exculpatory 'no' as to possible criminal activity."

40 661 F2d 404, 409 (5th Cir 1981) (holding that the exculpatory no doctrine did not apply to a defendant who lied to a customs official after he was assured that carrying large amounts of currency was not a crime, but need only be reported). The defendant lied twice, once before, and once after the official's assurances. The court ignored that the defendant might have still feared admitting the first lie, which could also have been a violation of $\S 1001$.

1683 F2d 894 (5th Cir 1982) (holding that the exculpatory no doctrine applied to defendants who were prosecuted for answering "no" to a question on their tax returns that asked whether they maintained any foreign bank accounts). The defendants could have answered "yes" and paid the tax without fear of penalty.

12 Id at 899-901.

4s "We emphatically reject the suggestion that the government should be allowed to coerce a person into admitting wrongdoing, on pain of prosecution under 18 USC $\S 1006$, simply because the person is 'connected with' a Federal Land Bank." 750 F2d at 862.

14 Id at $863 \mathrm{n} 22$.

48 Id at 863 (citations omitted).

18788 F2d 714, 719 (11th Cir 1986).

17 Id. Had Tabor told the truth, she would have incriminated herself. The government's argument was that Tabor had not presented any evidence on the issue at trial. The specific holding of the case was that the defendant need not prove that she feared selfincrimination. 
2. Exception if both justifications are implicated (Fourth, Eighth, and Ninth Circuits).

Other circuits have adopted a narrower formulation of the exculpatory no that requires an inquiry into both statutory purpose and the risk of self-incrimination. This version of the doctrine focuses on the extent to which the false statement interferes with agency functions and on whether a truthful response would have incriminated the defendant. The Ninth Circuit articulated the most frequently cited test for the exculpatory no doctrine in United States v Medina de Perez: (1) the false statement must be unrelated to a claim of privilege or a claim against the government; (2) the declarant must be responding to inquiries initiated by a federal agency; (3) the false statement must not impair the basic functions of the agency; (4) the inquiries must not constitute a routine exercise of administrative responsibility; and (5) a truthful answer would incriminate the defendant. ${ }^{48}$ The court justified this test on the grounds outlined in Paternostro: that a competent investigator's function is not impaired by exculpatory statements, and that application of $\S 1001$ to criminal investigations encourages inquisition as a method of criminal investigation. ${ }^{49}$

There are significant differences between the Medina de Perez test and the progeny of Paternostro, however. First, unlike the Fifth Circuit, the Ninth Circuit did not "see, in the context of a post-arrest interrogation, any meaningful distinction between an exculpatory 'no, I am not guilty,' and a more complete, evasive exculpatory response to a direct question." "Socond, because the test is conjunctive, ${ }^{, 1}$ there is no exculpatory no if the suspect did not fear self-incrimination. ${ }^{52}$

Finally, the Ninth Circuit test has two elements not usually considered in the Fifth Circuit cases: whether the question was administrative or investigative, and whether a false answer would im-

48 799 F2d at 544. See also United States $v$ Cogdell, 844 F2d 179, 183 (4th Cir 1988); United States v Taylor, 907 F2d 801, 805-06 (8th Cir 1990). The Sixth Circuit adopted the Medina de Perez test in United States $v$ Steele, 896 F2d 998 (6th Cir 1990), but that decision has been vacated pending reconsideration en banc. United States $v$ Steele, 909 F2d 862 (6th Cir 1990).

49 Medina de Perez, 799 F2d at 546-47.

so Id at $546 \mathrm{n} 9$.

61 United States v Becker, 855 F2d 644, 646 (9th Cir 1988).

s2 Curiously, the Medina de Perez definition would not apply to the Ninth Circuit's first beneficiary of the "exculpatory no," because he did not fear self-incrimination: rather, he lied about his identity to avoid being subpoenaed to testify at someone else's trial. United States v Bedore, 455 F2d 1109 (9th Cir 1972). 
pair the agency's function. ${ }^{53}$ Unfortunately, the line between administration and investigation is not sharp..$^{64}$ Consider, for example, United States $v$ Olsowy ${ }^{65}$ and United States $v$ Cogdell. ${ }^{56}$

Olsowy involved a man who, after requesting a replacement social security check, denied to a Secret Service agent that he had cashed his original check. This denial was under oath, after the agent had advised him of his rights and warned him that the agent knew he was lying. The Ninth Circuit held that his denial was not an exculpatory no because the Secret Service agent was acting in part in an administrative capacity in determining whether the defendant was entitled to a replacement check. ${ }^{57}$ In Cogdell, the Fourth Circuit, adopting and applying the same test, held that a defendant who had claimed a replacement tax refund check and then denied cashing the original to a Secret Service agent (again under oath and after identical warnings) had uttered an exculpatory no. The court distinguished Olsowy on the ground that Cogdell's replacement check had already been issued, ${ }^{58}$ and thus the Secret Service agent was only investigating a completed fraud. The panel was sensitive to the weakness of this distinction-after all, Olsowy too had already committed a crime by presenting his false claim. The court noted, "to the extent the Olsowy court's reasoning differs from ours, we find it unpersuasive." 59

\section{Other circuits.}

The reactions of the other circuits to the investigative use of $\S$ 1001 are hard to categorize because they have visited the issue infrequently. The Seventh and Tenth Circuits have adopted more restrictive variants of the exculpatory no. ${ }^{60}$ The First Circuit

s3 United States $v$ Rose, 370 F2d 1358, 1364 (9th Cir 1978); Medina de Perez, 799 F2d at 544. Although the Fifth Circuit has distinguished administrative from investigative inquiries, see $B u s h, 503 \mathrm{~F} 2 \mathrm{~d}$ at 815 , its definition of investigative has been so broad as to make the inquiry a formality. See the discussion of Hajecate at note 41 .

s4 See Becker, 855 F2d at 646 ("[i]t is difficult to draw a sharp distinction between administrative and investigative responsibilities"); Payne, $750 \mathrm{~F} 2 \mathrm{~d}$ at $863 \mathrm{n} 21$ ("we find the distinction unhelpful").

ss 836 F2d 439 (9th Cir 1988).

s6 844 F2d 179 (4th Cir 1988).

s7 Olsowy, 836 F2d at 442.

s8 Checks are issued without first conducting an investigation as part of standard IRS practice. Cogdell, 844 F2d at $180 \mathrm{n} 1$.

59 Id at $184 \mathrm{n} 5$.

Bo See United States $v$ King, 613 F2d 670, 674-75 (7th Cir 1980) (adopting a test that is narrower than Fifth Circuit doctrine in that it adds a further requirement that defendants be unaware that they are under investigation at the time of questioning; few defendants meet all of the court's criteria); and United States v Fitzgibbon, 619 F2d 874, 879-80 (10th 
adopted the Fifth Circuit's test, but then abandoned it, leaving the law unsettled. ${ }^{61}$ The D.C. Circuit has "never clearly adopted or rejected the doctrine," but it has refused to apply it to false responses on administrative reports. ${ }^{62}$

The Second Circuit has "never quite embraced the "exculpatory no' exception," but it is determined to "construe it narrowly." ${ }^{18}$ In United States $v$ Capo, ${ }^{64}$ the defendant was presented with checks indicating that he had been extorting bribes. Instead of denying any knowledge of the checks, he explained that one of the checks was payment for his winnings in a Super Bowl pool. When the investigators pointed out to him that the check predated the game, he responded, "Well, maybe she [the payer] knew I was going to win." voluntary and upheld the conviction.

\section{Problems}

This Section discusses two weaknesses with the exculpatory no exception. First, the justifications that courts offer in support of the doctrine are weak. Neither the Fifth Amendment nor the Supreme Court's reading of the statute's intent support the exculpatory no as it stands. Second, the exculpatory no is unworkable because its categories are indeterminate and fail to identify those situations that fall outside the statute's purpose.

1. The justifications for the doctrine are weak.

To the extent that the various formulations of the exculpatory no depend on a constitutional objection to compelled self-incrimi-

Cir 1980) (emphasizing the defendant's knowledge that lying to a customs officer was a crime).

${ }^{\circ 1}$ Chevoor, 526 F2d at 183-84 (adopting Fifth Circuit doctrine to explain that man prosecuted for perjury would not have incriminated himself by admitting previous lie to federal agent). See also Poutre, 646 F2d at 686 . Although, as discussed in note 29 , the court in Poutre reversed the defendant's conviction on other grounds, it decided that the "courtdrawn line between affirmative and exculpatory negative responses" was arbitrary, and given the then-imminent "legislative therapy" for $\$ 1001$ was unwilling to develop the doctrine. The proposed legislation to which the court referred, however, did not pass. Criminal Code Reform Act of 1979, S 1722, 96th Cong, 1st Sess (Jan 17, 1980); Criminal Code Revision Act of 1980, HR 6915, 96th Cong, 2d Sess (Sept 25, 1980). Congress failed to act before the end of the session. See Criminal Code Reform Act of 1981, S Rep No 97-307, 97th Cong, 1st Sess 2 (1981).

${ }^{62}$ United States v White, 887 F2d 267, 273-74 (DC Cir 1989) (affirming conviction of civil servant for false statement on standard GSA financial disclosure form).

ss United States v Capo, 791 F2d 1054, 1069 (2d Cir 1986), vacated in part on other grounds on reh en banc, 817 F2d 947 (2d Cir 1987).

ot Id.

ss 791 F2d at 1060. 
nation they are flawed. The Supreme Court has held that the Fifth Amendment never protects falsehoods, even if an incriminating response is apparently required by law. ${ }^{86}$ Thus, even the courts that ignore the fact that $\S 1001$ does not coerce speech or that dismiss the option of silence ${ }^{6 z}$ have no basis for claiming that the Fifth Amendment is implicated when suspects lie to federal agents. ${ }^{68}$

The legislative intent argument is stronger, but still flawed. It is true that the Congress that enacted $\S 1001$ never considered whether the statute should apply to the subjects of criminal investigations. But the Supreme Court has chosen to read Congress's silence as evidence of the statute's breadth: "The statutory language clearly encompasses criminal investigations conducted by the FBI and the Secret Service, and nothing in the legislative history indicates that Congress intended a more restricted reach for the statute." that relies on a distinction between investigative and administrative activities.

2. The exculpatory no defense relies on flawed distinctions.

Even if the exculpatory no exception were well founded, ambiguous phrases such as "simple negative statement" and "administration" display two distinct flaws. First, these categories are arbitrary-judges cannot argue meaningfully about them and they provide little guidance to potential defendants. Second, and more importantly, the categories are irrelevant-they do not adequately distinguish defendants who are dangerous to agency informationgathering from those who lie harmlessly to agents who prefer that they lie.

The distinction between simple denials and affirmative misrepresentations illustrates the inadequacy of the courts' sorting mechanisms. From the perspective of the suspect, the categories are meaningless; exculpatory denials can take many forms, and suspects are unlikely to appreciate that one form is criminal while

\footnotetext{
${ }^{83}$ Bryson, 396 US at 72.

${ }^{\circ 7}$ See, for example, Payne, 750 F2d at 862 (dismissing the argument that "the Fifth Amendment does not provide a 'license to lie,' " by distinguishing Supreme Court rulings). Some courts that have exempted defendants from \& 1001's penalties have ignored the third alternative--remaining silent-and referred to a "Hobson's choice" that defendants must make between confession and falsehood. See, for example, United States v Taylor, 105 Bankr 486, 494 (Bankr E D Ark 1989).

ss See White, 887 F2d at 274, citing Bryson, 396 US at 72, and United States $v$ Knox, 396 US 77, 82 (1969).

${ }^{69}$ Rodgers, 466 US at 477.
} 
another is not. From the perspective of the judge, the distinction provides little or no room for legal argument; decisions depend on a seemingly arbitrary choice between labels. In United States $v$ Bush, for example, the court split on whether detailed affidavits were simple denials; ${ }^{70}$ the majority held that they were. Such opinions do little to clarify the nature of the exception.

Even if judges can agree on a category for the statement, the category does not reflect the extent to which the defendant actually tried to interfere with the agency's processes. For example, the "denials" uttered by Paternostro, under oath, seem clearly to have been pre-planned, deliberate lies spoken by a suspect who knew his obligation to speak the truth. The Fifth Circuit held that he was not liable under $\S 1001$ because his statements amounted to "mere negative responses." 11 on the other hand, the "affirmative misrepresentation" about a Super Bowl pool in Capo seems to have been a flippant and perhaps despairing attempt to elude detection that had virtually no chance of success. The suspect had no notice of his obligation to speak the truth, and he had not prepared for the interview; nonetheless, the Second Circuit affirmed his conviction. ${ }^{72}$

The Medina de Perez test poses similar problems of arbitrariness and irrelevance when it distinguishes between investigation and administration. When are federal agents "monitoring compliance,"73 and when are they investigating a crime? Recently, the Ninth Circuit held that Customs Service criminal investigators can identify a suspect, record that he is aware of the currency regulations, dog his footsteps, and then ask him whether he is carrying currency, all the while keeping the action in an "administrative context." "Suspects are again unlikely to appreciate the distinction the court draws, and the decision seems arbitrary. Furthermore, the distinction is again irrelevant. Customs agents performing these sorts of "administrative" duties are no more (and no less) interested in eliciting the truth than FBI agents interviewing a suspect, and the lie itself is equally unlikely to harm the agency.

Significantly, no version of the exculpatory no asks whether the agency wants the protection of the statute. The Medina de Perez test comes closest by requiring the judge to determine

\footnotetext{
30 503 F2d at 819 (Roney dissenting).

${ }^{71}$ Paternostro, 311 F2d at 305.

72 Capo, 791 F2d at 1069:

73 United States v Alzate-Restreppo, 890 F2d 1061, 1066-67 (9th Cir 1989).

74 Id at 1067.
} 
whether the statement would impair the basic functions of the agency, ${ }^{75}$ but this element of the test is as subject to arbitrary decisions as the distinction between administration and investigation. ${ }^{78}$

On the whole, the justifications for the exculpatory no doctrine seem to reflect the opinion of the judiciary that $\S 1001$ gives federal police too much power over criminal suspects. Given the decisions of the Supreme Court, however, it is difficult to argue that the Constitution forbids punishing people for lying, or that the statute does not grant that power to investigative agencies. Whatever their justification, the tests for the exculpatory no are badly flawed. They provide arbitrary and obscure guidelines, and they do not sort out the liars who threaten agency informationgathering from those who do not. A better exception, or defense, to liability under $\S 1001$ should: (1) accept that $\S 1001$ grants federal police the power to demand that suspects not lie to them; (2) focus on the ways in which the statute can be applied in violation of its purpose; and (3) provide a test for the misapplication of the statute that defendants, investigators, and courts can understand and use.

\section{The "INDUCed LiE" Defense}

This Section proposes an affirmative defense, the "induced lie," to replace the exculpatory no. Because the purpose of $\S 1001$ is to protect agency information-gathering, $\S 1001$ should not apply when agents actually prefer that suspects speak, even if they lie. Accordingly, the statute should be presumed not to apply unless the agent has warned the suspect that lying is a crime and that silence is permitted. There are two caveats, however. First, the statute should always apply when a response is required by law. Second, the government should be able to rebut the presumption that the statute does not apply when warnings were not given by showing that the suspect was predisposed to lie to the agency. After justifying a departure from the literal language of the statute, this Section discusses the induced lie defense in detail.

\footnotetext{
75799 F2d at 544.

${ }^{76}$ For example, compare Olsowy, 836 F2d at 442 (concluding that Olsowy's "false statements plainly impaired the Treasury Department's basic function of determining whether he was entitled to a replacement check"), and Cogdell, 844 F2d at 184 (concluding that Cogdell's false statements, in nearly identical circumstances, could not "pervert an agency's basic functions").
} 


\section{A. The Problem}

The investigative use of $\S 1001$ presents a classic example of overinclusive statutory language. As discussed in Section I, Congress enacted $\S 1001$ to punish people who filed false reports with the government when such reports were required. The Supreme Court has taken the words of the statute to indicate a broader intent to protect agency information-gathering, whether or not the agency may require a response. Unfortunately, the literal language of the statute can also be applied to people who lie in situations where agency information-gathering is furthered by lies.

When criminal statutes are involved, the problem of overinclusiveness is particularly grave. It is difficult to justify literalism when the price of legislative imprecision is liberty. When the Supreme Court first recognized the defense of entrapment, the judicial response to a similar problem of overinclusive language, it proposed that:

general terms descriptive of a class of persons made subject to a criminal statute may and should be limited where the literal application of the statute would lead to extreme or absurd results, and where the legislative purpose gathered from the whole Act would be satisfied by a more limited interpretation. ${ }^{77}$

The investigative use of $\S 1001$ produces results that are both extreme and absurd. The task for the courts is thus to construct a narrow and workable exception to $\S 1001$ 's sanction that eliminates absurdity and better satisfies congressional intent. The Eighth Circuit had a workable exception-exempt all statements made to investigative agencies on the grounds that they were without "jurisdiction" within the meaning of the statute ${ }^{78}$-but the Supreme Court found it too broad and "unduly strained." Other circuits have embraced the exculpatory no. Unfortunately, this exception has little legal foundation, uses arbitrary distinctions, and largely

7 Sorrells $v$ United States, 287 US 435, 447-48 (1932) (quoting United States $v$ Katz, 271 US 354, 362 (1926)) (emphasis added).

78 Friedman, 374 F2d at $367-68$. Unlike the investigative/administrative line drawn by the Ninth Circuit, the Eighth Circuit test depended on the identity of the agency, not on the activities of the agent. Friedman, 374 F2d at 368-69 (finding FBI had no "jurisdiction" over false reports of crime).

79 Rodgers, 466 US at 484 . The Court noted that punishing people who " 'knowingly and willfully" " make false reports of crime "is not so 'absurd or glaringly unjust,' as to lead us to question whether Congress actually intended what the plain language of $\S 1001$ so clearly imports." Id (citing Sorrells, 287 US at 450). 
misses the real issue. The proposed induced lie defense attempts to resolve these problems.

\section{B. The Defense}

Although investigators occasionally set up violations of $\S 1001$ deliberately, ${ }^{80}$ the perversion of $\S 1001$ 's purpose probably occurs more often because agents conduct interviews in ways designed to get the suspect to talk. As a result, the suspect talks, but lies. A zealous prosecutor may then choose to bring a charge, not realizing that the investigator, had she thought about it, might have preferred those lies to silence.

Because getting suspects to talk is normal practice, it is probably pointless to inquire about the investigator's preferences in each case. First, the investigator may have had no conscious preferences at the time of the interview. Moreover, it seems likely that an investigator who must reconstruct her thought processes will be strongly inclined to defend the propriety of the prosecution under $\S 1001$. Accordingly, not only would a case-by-case inquiry be timeconsuming and expensive, it would often reveal only a biased account of a hypothetical truth.

Instead, the issue should be whether the investigator has warned the interviewee that lying is a crime and that he may remain silent. This inquiry alone, however, exempts too many to whom § 1001 should apply: those who lie when a response is required, and those who would lie even in the absence of governmental misconduct. statute.

1. Warnings as a cure for systemic misapplication of the

The danger of systemic perversion of the statute's purpose calls for a systemic cure. The cure is a procedural reform: investigators should tell suspects and other interviewees that lying is a crime and that silence is permissible. Giving a warning that lying is a crime is a nearly costless step that would increase compliance with $\S 1001$. Notice that the suspect may remain silent reinforces the first warning and prevents the investigator from implying that the interviewee must submit to inquisition. Together, these warnings would indicate in a clear and unequivocal fashion that the investigator really does want truth or silence.

80 See note 20. 
The warnings would also change the nature of the suspect's trilemma, making it more difficult for the investigator to induce a lie. An interview with a suspect who has been threatened with punishment if he lies and told he may remain silent will likely be qualitatively different from an informal interview with a suspect who has received neither warning. The decision will be difficult, but any choice the suspect makes will be informed and deliberate. His difficulty, moreover, will be the result of his own culpability, not the government's action. Without such warnings, the suspect's decision would be deceptively easy; to tell a lie, and thereby commit a felony, would often appear to be the only sensible choice. Such a lie should be considered "induced" by the investigation, and hence beyond the scope of $\S 1001$.

It is important to note that, unlike an exclusionary rule, a failure to warn would not require the suppression of the interview or serve as a bar to prosecution for any substantive offense other than the lie. Nor would the required warnings give "the federal judiciary a 'chancellor's foot' veto over law enforcement practices"; ${ }^{11}$ federal agents would still be able to conduct "informal" interviews, but they would have a harder time convicting suspects of doing what comes naturally in such interviews. When, on the other hand, agents conduct a formal interview, they could rely on the deterrent power of the statute they invoke. ${ }^{82}$

2. Refinements to the induced lie defense: required responses and predisposition.

Requiring warnings in all interviews is not a panacea. Inevitably, investigators or agencies will occasionally fail to give warnings, and in some of these cases, people who have uttered false statements that Congress actually wanted to sanction will go free. These people fall into two categories: those who violate Congress's original intent by lying when their response is required, ${ }^{\mathbf{8 3}}$ and

at United States v Russell, 411 US 423, 435 (1973).

"2 This approach also seems in accord with congressional consideration of the problem. The most recent bills on the topic imposed penalties on false statements to law enforcement officials but provided procedural protections. The House bill provided that such prosecutions must be based on a verbatim recording, made with the suspect's knowledge. Criminal Code Revision Act of 1980, HR 6915, 96th Cong, 2d Sess, § 1742 (1980). The Senate bill required that prosecutions for false statements could only go forward against people who had been advised that lying was a crime. Criminal Code Reform Act of 1981, S 1630, 97th Cong, Ist Sess $\S 1343(a)(1)(A)$ (1981).

"3 In Gilliland, for instance, the defendants were required to report the amount of oil they produced or received on a monthly basis. 312 US at 89-90. 
those who violate the broader purpose of $\S 1001$ by lying because they plan to interfere with agency information-gathering. The induced lie defense should account for these groups to conform to the statutory purpose.

a) Required responses. Making a false statement on a required report is exactly what Congress wanted to deter when $\S 1001$ was enacted. To limit the application of the statute in this context would be a clear violation of congressional intent. Accordingly, federal agencies should not have to provide warnings when a response is required.

Support for this exception to the induced lie defense is found in the observation that federal agencies are unlikely to prefer lies to silence on required reports. Because the vast majority of such reports are filled out by law-abiding citizens, a refusal to respond is likely to be significantly more helpful to agency information-gathering than a false statement that may slip past the agency. Agency practices corroborate this analysis. Unlike investigative agents, a large number of federal government forms warn citizens that there are penalties for lying, ${ }^{84}$ indicating that the agencies involved prefer silence to lies.

It is also unlikely that people who lie when required to respond are in any way lured into their crime. From the defendant's perspective it can hardly come as a surprise that a response that is required must also be truthful. Unlike the criminal investigation context, a lie in such a situation is not induced by the government.

b) "Intentional" violations. The statute should also apply, even if no warnings are given, to cases in which the defendant was predisposed to lie. In such a case, the lie cannot have been induced by the investigation-there is no causal nexus between the lie and agency conduct. In this sense, the induced lie is similar to entrapment. The entrapment cases establish that when an individual is predisposed to commit a crime, government conduct that makes his crime more likely to occur does not justify exculpation. ${ }^{85}$ The benefit of the predisposition exception to the induced lie defense is

84 See, for example, IRS Form 1040 (United States Individual Income Tax Return) (1990) ("Under penalties of perjury, I declare that . . . to the best of my knowledge and belief, they are true, correct, and complete."); Customs Form 6059B (Customs Declaration) ("False statements on the report may lead to . . . criminal prosecution."); Standard Form 171 (application for federal employment) ("[Y] $[$ ou may be punished by fine or imprisonment [for making a false statement on any part of the application].").

${ }^{85}$ Russell, 411 US at 433-36 (no defense of entrapment when undercover agent provided essential ingredient for manufacture of illegal narcotic to predisposed defendant). 
that it captures those who most harm the information-gathering process: those who deliberately plan to mislead an agency.

The difficulty with this element of the induced lie is in defining its boundaries. In some sense, almost every guilty suspect who lies under questioning is predisposed to do so. Most criminals probably think about what they will say if asked about their crime. Moreover, unlike an entrapment case, no police officer plants the idea of violating $\S 1001$ in the suspect's mind. Predisposition must involve more than a propensity to lie when asked incriminating questions. As used in the induced lie defense, a predisposed defendant is one who knows that he must lie to a federal agent, and plans to do so in advance.

The definition may best be illustrated by comparing three cases. In the first case, United States $v$ Tabor, an IRS agent appeared at the defendant's door with a deputy sheriff, told her that he was investigating a man named Forest Weeks, and asked her about the procedures she used when she notarized documents. The defendant claimed that she always required that documents be signed in her presence, when in fact she had notarized the document in question outside the presence of those who had signed it. ${ }^{86}$ In the second case, United States $v$ Rodgers, a distraught husband told the FBI that his wife was planning to kill the President. ${ }^{87}$ In fact, his wife had run off, and Rodgers wanted the FBI to help him find her. ${ }^{88}$ In the third case, United States $v$ Johnson, the defendant convinced a friend to sign an affidavit stating that the friend had lent money to the defendant in order to explain the incongruity between the defendant's assets and his reported income. ${ }^{89}$ He then presented the affidavit to the IRS at his next scheduled interview to support his claim of innocence. ${ }^{80}$

It is unlikely that Tabor was predisposed to lie to a federal agent. She never wanted to discuss the subject with any law enforcement officer. Rodgers was clearly predisposed; he planned to lie to the FBI from the start, and his whole scheme depended on the success of his lie. Johnson is more ambiguous. No one desires an audit, and Johnson's tax evasion scheme did not necessarily depend on lying to an auditor. But, on the other hand, once the audit

s6 788 F2d 714 (11th Cir 1986). One of the alleged signators had been dead for five weeks when her signature was notarized. Id at 716 .

866 US at $476-77$.

ss Id at 477 .

so 530 F2d 52, 54 (5th Cir 1976).

20 Id. 
was in progress, Johnson considered his options, had time and opportunity to seek legal advice, and deliberately prepared a false document.

Johnson lied because he faced a trilemma. But his lie was unhurried and was carefully crafted to derail the investigation. It seems reasonable to allow the factfinder to determine which of these factors predominated. It is also more in keeping with traditional notions of criminal liability to make Johnson's culpability depend on his state of mind, rather than an objective but fuzzy evaluation of whether the document itself was an affirmative misrepresentation of fact ${ }^{91}$ or an exculpatory denial.

\section{Summary of the defense.}

The induced lie is based on the observation that guilty suspects will usually lie when asked incriminating questions and that investigators, either consciously or systematically, may prefer lies to silence. The induced lie does not solve the suspect's trilemma, but it makes the full ramifications of the problem clear to him. The defense thus prevents investigators from luring suspects into crimes that they would prefer not to commit. Because the defense is based on a reform of investigative procedures, however, it is almost inevitably overinclusive: federal agents will occasionally fail to give warnings for reasons unrelated to their preference that suspects talk. Such a failure, however, should not always bar prosecution. The judge may find that a response was required anyway, or the jury may find that the defendant was not induced to lie because of his predisposition, and either finding should be adequate for conviction.

At trial, the induced lie defense requires three levels of decision. First, the judge must determine whether a response was required. If it was, the induced lie defense does not apply. Any false statements made in such a case are subject to $\S 1001$ 's penalties. Second, the court must determine whether warnings were given. If the investigator did not warn the suspect, or the warnings were inadequate, the defendant should be presumptively free from $\S$ 1001 liability. Finally, the prosecution may choose to rebut this presumption by introducing evidence that the defendant was predisposed to lie. ${ }^{22}$

92 Id at 55. The court affirmed Johnson's conviction on this basis.

92 To invoke the induced lie defense, the defendant must at least raise the possibility that he lied. There should be no procedural bar to a defendant who wants a jury instruction on the induced lie but who is not prepared to admit that he lied, Mathews $v$ United States, 
The test for the induced lie should lead to more certain results. Whether and when a response is required is an almost purely legal question. Whether warnings were given is usually a simple yes or no factual decision. Predisposition is a common issue of mens rea that juries must decide in other contexts. Although it may be more difficult for agents and courts to recognize than the first two elements, predisposition at least promotes deterrence by making guilt or innocence depend on a factor the defendant knows, his own mental state, rather than on ostensibly objective factors that even courts seem unable to determine.

\section{ConCLusion}

The authority to force suspects to admit their guilt either by words or by silence is an unusual power in the hands of an investigative agent. But the Supreme Court has decided that such authority is available to investigative agencies under 18 USC $\S 1001$. Because the exculpatory no is an attempt to limit that grant of authority, it stands on shaky legal ground. More importantly, the doctrine depends on unworkable and seemingly irrelevant categories.

The flaws in the exculpatory no should not lead to a rejection of any defense, however. It is perverse to punish people under a statute designed to protect information-gathering when agency practices indicate that investigative agents actually prefer to be lied to so long as suspects talk. The induced lie defense is not designed to limit the authority that $\S 1001$ apparently grants to federal police. Such a limitation is properly a job for Congress. Instead, the induced lie identifies those situations in which application of the statute does not further its purpose. Although the de-

485 US 58, 63 (1988) (defendant may raise contradictory assertions in entrapment case), but the availability of an instruction on the induced lie would not solve all the defendant's problems. If the $\S 1001$ charge is joined with the substantive crime about which the defendant lied, the jury may take the evidence that the defendant lied as an indication of his guilt on the other offense. The more vigorously the defendant makes his affirmative defense under $\$ 1001$, the more deeply he digs his own grave on the other charge.

This problem may be resolved by severance under Rule 14 of the Federal Rules of Criminal Procedure, which provides in relevant part: "If it appears that a defendant ... is prejudiced by a joinder of offenses ...., the court may order an election or separate trial of counts ... or provide whatever other relief justice requires." Although the defendant must make "a convincing showing that he has both important testimony to give concerning one count and strong need to refrain from testifying about the other," Baker $v$ United States, 401 F2d 958, 977 (DC Cir 1968), a defendant charged with a § 1001 violation and another crime will often be able to meet the standard. 
fense cannot substitute for a more precise statute, it does ensure that the current statute is not twisted into absurdity. 